\title{
Isu-Isu Krisis Dalam Novel-Novel Dystopian Science Fiction Amerika
}

\author{
Muajiz Muallim \\ Universitas Gadjah Mada \\ muajizmuallim@gmail.com
}

\begin{abstract}
Abstrak
Tulisan ini terfokus pada isu-isu dan wacana tentang krisis yang ada pada novel-novel dystopian science fiction (dystopian sf). Dalam kasus ini tiga trilogi Hunger Games Trilogi (2008-2010), Maze Runner Trilogi (2009-2011), Divergent Trilogi (2011-2013) dijadikan objek utama untuk melihat sejauh mana teks novelnovel dystopian sf ini mengangkat isu-isu dan wacana tentang krisis di dalamnya. Novel-novel dystopian sf yang merupakan wacana tandingan dari novel-novel utopian sf kini tidak lagi menghadirkan elemenelemen masa depan yang utopis, melainkan menghadirkan kemungkinan-kemungkinan terburuk di masa depan. Terlihat bahwa penulis-penulis dystopian sf menghadirkan narasi-narasi tentang krisis, kemiskinan, kesuraman, dan pesimisme dalam novel-novelnya. Hal inipun terbaca sebagai salah satu bentuk kritik dan peringatan yang penulis-penulis tersebut coba sampaikan ke pembaca melalui teks fiksi. Pada akhirnya, kondisi krisis yang tampak pada teks novel-novel dystopian sf ini memungkinkannya memiliki relasi dengan sejarah dunia di luar teks tersebut.
\end{abstract}

Kata kunci: krisis, dystopian science fiction, Amerika, sejarah.

\begin{abstract}
This paper focuses on issues and discourses about the crisis that existed in the dystopian science fiction (dystopian sf) novels. In this case, Hunger Games Trilogy (2008-2010), Maze Runner Trilogy (2009-2011), Divergent Trilogy (2011-2013) are the main object to see how far the text of dystopian sf novels address issues and discourses about the crisis within. Dystopian sf novels that are the counterdiscourse of utopian sf novels has no longer present the utopian elements of the future, but, contrastly present the worst possibilities of the future. It appears that the dystopian sf writers present narratives about crisis, poverty, darkness, and pessimism in their novels. It even reads as a form of criticism and warning that the writers are trying to convey to the reader through fictional texts. In the end, the conditions of crisis seen in the text of these dystopian sf novels open its relationship with the world's history outside the text.
\end{abstract}

Keywords: crisis, dystopian science fiction, America, history.

\section{Pendahuluan}

Sejak awal abad ke 20, karya distopia mulai bermunculan dan seakan tampil sebagai pemain pengganti dari semangat utopia yang perlahan-lahan mulai ditinggalkan oleh masyarakat modern. Dalam dunia sf, semangat distopia pun menjadi gairah baru bagi penulis-penulis sf untuk menghidupkan kembali masa kejayaan sf yang sempat redup sejak ketegangan antar negara barat yang berujung pada dua perang dunia. Kemunduran utopia tersebut tidak lepas dari kejenuhan masyarakat terhadap mimpi-mimpi yang tidak kian terwujud dan malah makin memburuk, seperti timbulnya perang, krisis ekonomi, politik dan moral. Para pembaca sf pun mulai mencari-cari bacaan yang lebih bisa menggambarkan dan mewakili kondisi yang sedang mereka rasakan.

Kata "distopia" atau "dystopia" sering digunakan sebagai lawan kata "eutopia" atau "utopia” atau sering juga disebut anti-utopia, counterutopia, inverted utopia yang merujuk pada sebuah 
gambaran tentang kondisi dunia yang lebih buruk dibanding dunia yang kita huni sekarang. Istilah ini pertama kali dilontarkan oleh Stuart Mill pada sebuah pidato parlementer pada tahun 1868, namun penggunaanya lebih cocok jika dikaitkan dengan Quest for Utopia (1952) karya Glenn Negley dan J Max Patrick. Anthony Burgess, seorang penulis sf berkebangsaan Inggris, dalam karya Nineteen Eighty Five (1978) bahkan menganggap bahwa kata "cacotopia" (gabungan antara "cacophony" dan "utopia" yang merujuk pada gambaran pemerintahan atau kekuasaan yang sangat buruk) lebih cocok untuk merujuk pada kondisi tersebut.

Layaknya utopia, distopia juga memberikan gambaran tentang masa depan, akan tetapi lebih merujuk pada ketakutan terhadap masa depan dunia yang akan datang yang seringkali merupakan sebuah bentuk propaganda. Konsep utopia telah terbukti menumbuhkan harapan umat manusia akan kehidupan dan masa depan yang lebih baik, namun juga tidak dipungkiri bahwa bersama dengan itu, juga tumbuh ketakutan akan kekecewaan yang tidak dapat terelakkan jika hal tersebut tidak terlaksana. Olehnya itu, bebarapa ahli mempercayai bahwa konsep distopia tumbuh pasca utopia dinilai gagal memberikan perubahan yang dijanjikan pada dunia. Hal tersebut dapat dilihat pada gambaran yang dilakukan I F Clarke dalam bibliografinya The Tale of the Future (1978) yang merupakan sebuah peringatan tentang bencana yang akan dialami masyarakat dunia jika sistem monarki kembali diberlakukan.

Gambaran tentang distopia ini mulai berkembang di akhir abad ke 19. Contoh gambaran kontras antara utopia dan distopia ditunjukkan dengan cerdik oleh Jules Verne melalui kota Frankville dan Stahlstadt dalam The Begum's Fortune (1879). Materialis rakus yang membangun kota Stahlstadt tersebut juga mengilhami ideologi yang disematkan oleh H C Marriot Watson dalam Erchomenon (1879). Selain itu, ada juga Walter Besant yang termasuk melahirkan dua karya distopia awal yakni Revolt of Man (1882) dimana ada sosok pemimpin wanita yang berkuasa namun mendatangkan konsekuensi buruk., dan The Inner House (1888) yang berusaha menjelaskan bahwa keabadian (kekuasaan) akan menghasilkan stagnasi sosial. Tidak terkecuali, seorang pegiat utopia terkemuka seperti H.G.Wells juga ikut memproduksi karya dystopia, yang menceritakan tentang apa jadinya dunia jika kubu sosialime tidak menang, yang diceritakannya dengan apik dalam $A$ Stories of the Days to Come (1899) dan When the Sleepers Awakes (1910). Ia juga membuat alien pertama dalam cerita dystopia pada penggambarannya terhadap masyarakat Selenite (suatu makhluk yang menyerupai serangga yang membuat peradaban di bulan) dalam The First Men in The Moon (1901). Robert Hugh Benson juga melakukan protes keras terhadap sekularisme, humanisme, dan sosialisme yang berakhir dengan sebuah penyingkapan dalam karyanya Lord of The World (1907).

Meskipun karya-karya tersebut tampaknya merupakan reaksi ataupun kritik terhadap idealisme tertentu, namun kekhawatiran mendasar yang para penulis tersebut isyaratkan sebenarnya sama. Penekanannya mungkin saja berbeda, tapi inti dari karya-karya distopia tersebut tetap saja ada pada 
opresi dan pengawasan super ketat terhadap masyarakat oleh kelompok elit tertentu. Wells dalam The First Men in the Moon menggunakan model metafor "sarang semut" dalam karya distopianya untuk menggambarkan sebuah masyarakat yang membangun peradaban di bulan yang ia beri nama sebagai Selenite, dan model penggambaran seperti Wells ini kemudian menjadi sebuah formula yang diikuti oleh beberapa penulis lainnya pada waktu itu. J D Beresford dan Esme Wynne-Tyson dalam The Riddle of the Tower (1944) mengimplikasikan bahwa bencana paling mendasar yang dihadapi oleh sekelompok masyarakat adalah Automatism (kecenderungan kemenangan sekelompok masyarakat organik atas individu). Analisis paling mendetail terhadap kekhawatiran tersebut, dan mungkin saja merupakan karya distopia yang tidak dapat dilupakan oleh kritikus sf adalah Nineteen EightyFour (1949) karya George Orwell, yang memperlihatkan pesimisme dan kekecewaan Orwell terhadap kelas pekerja di Britania Raya yang tidak mampu keluar dari opresi dan dominasi. Selain, karya-karya besar Orwell, beberapa karya -karya sf yang dianggap sebagai pionir distopia seperti We (1924) karya Yevgeny Zamyatin, dan Brave New World (1932) karya Aldous Huxley.

\section{Karya-karya dystopian science fiction} (dystopian sf) merupakan karya sf yang mengusung semangat dystopia namun tida melepaskan unsur-unsur sf dalam membangun narasinya. Ini membuat karya dystopian sf berbeda dengan karya sf awal. Sebagai contoh, di dalam karya-karya dystopian sf teknologi tidak lagi sepenuhnya digambarkan sebagai sarana untuk men- capai kesejahteraan dan kemakmuran hidup manusia di masa depan seperti yang tergambarkan pada karya sf awal yang cenderung utopis, akan tetapi teknologi cenderung dinilai sebagai alat untuk meraih kekuasaan atau untuk mempertahankan kekuasaan yang berlaku di tengah masyarakat. Selain itu, dunia yang dibangung penulis terlihat sebagai dunia masa depan yang lebih buruk berbeda dengan mimpi-mimpi yang dijanjikan dalam karya sf sebelumnya. Hal tersebut pun membuat sebagian orang menilai karya-karya dystopian sf terkesan sebagai karya yang pesimistik dan anti masa depan. Namun sebagian lainnya (terutama bagi pegiat distopia) justru melihat hal tersebut sebagai bentuk kritik dan peringatan terhadap kondisi dunia saat ini yang bisa saja membawa kepada kondisi dunia yang lebih buruk seperti yang tergambarkan dalam narasi-narasi distopia.

Hingga saat ini, karya-karya dystopian sf pun semakin diminati pembaca fiksi, terutama dengan berbagai kondisi krisis yang tengah melanda masyarakat dunia. Dalam kurun waktu sepuluh tahun terkahir ini, karya-karya dystopian sf pun selalu berhasil meraup keuntungan yang tidak sedikit pada penjualannya (dalam berbagai bentuk dan adaptasinya). Bahkan tidak sedikit karya-karya bergenre lain yang menggabungkan elemen-elemen distopia dalam narasinya juga berhasil meraih penjualan yang tidak sedikit, seperti The Nightingale (2015) oleh Kristin Hannah, The Sympathizer (2015) oleh Viet Than Nguyen yang sempat meraih Pulitzer di tahun ini, dan masih banyak karya popular lainnya. Karya-karya seperti Hunger Games Trilogi (2008-2010), Maze Runner Trilogi (2009-2011), Divergent Trilogi (2011-2013), pun diyakini 
menghidupkan kembali popularitas karya-karya dystopian sf dalam bentuk novel sepuluh tahun terakhir ini (melihat tingkat produksi, adaptasi dan penjualannya yang massif). Keseluruhan hal tersebut tentunya tidak terlepas dari pola-pola yang ditawarkan karya-karya distopia sf untuk pembaca. Untuk itu, dalam tulisan ini, novelnovel Hunger Games Trilogi, Maze Runner Trilogi, Divergent Trilogi akan dijadikan bahan tinjauan dalam melihat isu-isu krisis yang sangat melekat pada narasi novel-novel dystopian sf. Hal ini juga mempertimbangkan kepopuleran gaya penulisan dystopian sf, yang terdapat pada tiga trilogi tersebut, yang semakin digemari pembaca muda saat ini.

\section{Tiga Trilogi Dystopian Sf Dan Narasi Krisis}

Sebagai (masih) bagian dari sf, trilogi Hunger Games, Maze Runner, dan Divergent juga tentunya meracik tiap latar ceritanya dalam bentuk masa depan. Pemanfaatan masa depan inipun menjadi formula tersendiri yang membuat karya-karya sf ataupun dystopian sf berbeda dengan genre fiksi popular lainnya. Di masa kejayaan utopian sf, latar masa depan menjadi sebuah representasi dari harapan, angan-angan, cita-cita, bahkan pencapaian masyarakat modern saat itu yang tengah berada dalam euphoria kegemilangan peradaban yang ditandai dengan penemuan-penemuan sains dan teknologi. $\mathrm{Na}$ mun, seiring berjalannya waktu, harapan dan cita-cita tersebut ternyata tidak seindah yang diangan-angankan di masa lalu. Rentang sejarah pun memperlihatkan transformasi kultur masyarakat dunia dari yang awalnya masyarakat agraris, modern, industri, hingga menjadi kapitalis. Lahirlah istilah bahwa modernisme gagal memenuhi janji-janjinya. Teknologi yang merupakan salah satu representasi kemajuan peradaban ternyata tumbuh sebagai pisau bermata dua. Di satu sisi ia melahirkan peradaban namun di sisi lain juga melahirkan ancaman dan efek destruktif terhadap peradaban manusia, yang baru disadari setelah masyarakat menyaksikan secara langsung dua perang besar dunia yang memporak-porandakan kehidupan sosial, ekonomi dan politik yang telah susah payah dibangun. Efek dari kemajuan teknologi terhadap peradaban manusia saat ini tentunya sangat kompleks untuk dijabarkan satu persatu. Namun, jika menggunakan sudut pandang distopia, pengembangan sains dan teknologi oleh manusia merupakan salah satu objek yang "disalahkan" atau dinilai "bertanggung jawab" terhadap kekacauan yang terjadi, khususnya dari sudut pandang masa depan dalam tiga karya trilogi dystopian sf tersebut.

Jika klaim pada tiga karya dystopian sf itu ditindak-lanjuti, itu berarti kondisi terpuruk yang ditampilkan (dalam format masa depan) tidak lain adalah suatu bentuk penyalahan terhadap masa lalu yang dinilai sebagai penyebab dari semua kondisi yang dialami dalam teks. Dalam tiga trilogi dystopian sf tersebut, narasi-narasi tentang masa lalu memang sangat sedikit yang diceritakan. Walaupun diceritakan itu hanyalah secuil dari keseluruhan narasi yang dibangun dalam teks. Meskipun demikian, hal tersebut tetap saja menjadi pondasi ataupun akar permasalahan yang urgen dalam teks, karena masa depan merupakan sebuah kontinuitas sejarah dari masa lalu. Akan tetapi, apa 
yang ada di dalam teks fiksi tersebut tentunya tidak secara langsung merujuk kepada kondisi sejarah, seperti yang dikemukakan oleh Pfaelzer bahwa "Both genres (utopian sf dan dystopian sf) revert to the voyage extraordinaire to avoid historical process" (Pfaelzer, 1980: 62). Latar masa depan dan kisah-kisah hiperbolik yang keluar dari kondisi dunia nyata (yang ada dalam dystopian sf) merupakan bagian dari usaha pengelakan terhadap sejarah. Lagi-lagi dalam hal ini diperlukan interogasi terhadap teks fiksi yang metaforis dan simbol-simbol yang tersemat di dalamnya. Jika demikian adanya, yang menjadi pertanyaan kemudian adalah masa lalu yang mana dan yang seperti apa yang dibicarakan dalam dystopian sf? Berikut ini merupakan gejala-gejala dalam teks yang dapat dijumpai yang secara implisit merujuk pada peristiwa-peritiwa sejarah atau kondisi dunia nyata di luar teks.

Dalam karya-karya sf yang mengusung semangat distopia, pembaca akan selalu menemukan latar-latar masa depan yang destruktif atau tidak ideal. Namun berbeda dengan fiksi bergenre disaster yang mana kehancuran umumnya disebabkan oleh alam, dystopian sf cenderung disebabkan oleh manusia sendiri seperti situasi pasca perang, kerusakan lingkungan, krisis sosial dan ekonomi. Walaupun pola ini jelas berbeda dengan pola utopis yang dicita-citakan masyarakat modern, namun uniknya, pola seperti ini dianggap lebih realistis oleh pembaca saat ini ketimbang pola-pola sf sebelumnya karena tidak hanya menampilkan satu sisi dari kehidupan. Krisis, kehancuran dan kekerasan merupakan sisi lain dari kehidupan yang tidak dapat disembunyikan terus-menerus. Hal ini sejalan dengan apa yang dikatakan Adi (2008: 97) bahwa untuk meyakinkan audiens tidaklah harus selalu menampilkan latar yang indah dan damai yang hanya mewakili salah satu dari realita kehidupan, sisi lain seperti pertengkaran, kerusakan dan perang juga merupakan situasi yang sering dirasakan di dunia nyata. Bisa jadi pembacapembaca muda saat ini sedang menginginkan hal seperti ini. Seperti penggambaran tentang kelamnya kehidupan masyarakat yang setiap hari harus dihantui terror kelaparan cenderung menghiasi narasi-narasi dari karya-karya dystopian sf.

Dalam tiga trilogi Hunger Games, Maze Runner, dan Divergent, kondisi yang digambarkan merupakan kondisi yang tidak ideal bagi penulis di dunia nyata, baik masyarakatnya maupun kondisi sosial yang tergambar dalam teks. Oleh karena itu, dalam karya-karya tersebut, pembaca akan banyak menemukan narasi-narasi yang membicarakan tentang kehancuran, kemiskinan, pesimisme, kerakusan, pemerintah yang korup dan lain-lain. Sehingga penggambaran kota dan kehidupan masyarakat yang digambarkan tidak pula jauh dari hal tersebut. Dari penggalan-penggalan teks yang telah dibahas di sub bab sebelumnya, dapat dilihat suatu kesamaan, selain menyebutkan wilayah yang merepresentasikan AS, penggalan teks itu juga memperlihatkan kesaamaan situasi cerita yang tidak lepas dari kesuraman, kehancuran, ketakutan, dan ketertekanan akibat pengawasan yang super ketat yang dilakukan oleh penguasa.

Dalam Trilogi Divergent misalnya, masyarakat diceritakan hidup dalam sistem pemerintahan yang diwariskan turun-temurun oleh pendahulu 
Poetika : Jurnal Ilmu Sastra

Vol. V No. 1, Juli 2017

mereka. Sistem tersebut membagi masyarakat dalam kelas-kelas yang memisahkan masyarakat menurut sistem kerja yang berlaku. Jika seseorang tersebut cerdas maka akan berkerja untuk kota itu sebagai ilmuan dan jika seorang tersebut jujur maka akan berperan dalam bidang hukum. Namun di balik itu semua, ada kesenjangan yang diabaikan oleh penguasa pemerintahan. Dalam cerita, ada kelompok yang disebut factionless yang merepresentasikan dampak dari kebobrokan sistem dalam cerita tersebut. Factionless merupakan kelompok yang tidak berhasil memasuki kategori manapun dalam sistem kerja. Sehingga kelompok ini terbuang dan terasingkan dari komunitas masyarakat. Mereka pun hidup tak menentu dan terjerat kemiskinan karena hak-hak kemanusiaan mereka tidak dianggap oleh pemerintah. Pada kelompok inilah, Roth mencoba menggambarkan kemiskinan, keterpurukan, kesenjangan sosial, yang tidak lain adalah korban dari sistem yang rusak yang dikontrol oleh kekuasaan yang korup.

What if they tell me that I'm not cut out for any faction? I would have to live on the streets, with the factionless. I can't do that. To live factionless is not just to live in poverty and discomfort; it is to live divorced from society, separated from the most important thing in life: community. (Roth, 2011: 14)

Just past the Abnegation sector of the city is the stretch of building skeletons and broken sidewalks that I now walk through. There are places where the road has completely collapsed, revealing sewer systems and empty subways that I have to be careful to avoid, and places that stink so powerfully of sewage and trash that I bave to plug my nose. This is where the factionless live. Because they failed to complete initiation into whatever faction they chose, they live in poverty, doing the work no one else wants to do.
DOI $10.22146 /$ poetika.25810

ISSN 2338-5383 (print) ; 2503-4642 (online)

They are janitors and construction workers and garbage collectors; they make fabric and operate trains and drive buses. In return for their work they get food and clothing, but, as my mother says, not enough of either.' (Roth, 2011: 16)

The factionless lead us down the street and left into a grimy alleyway that stinks of garbage. Rats scatter in front of us with squeaks of terror, and I see only their tails, slipping between mounds of waste, empty trash cans, soggy cardboard boxes. I breathe through my mouth so I don't throw up. (Roth, 2012: 37)

Kutipan di atas menunjukkan bagaimana Roth menggambarkan kontradiksi dan ironi melalui sebuah kelompok yang terasingkan dan terbuang dari masyarakat. Factionless merepresentasikan inferioritas sebuah kelompok masyarakat diantara kelompok masyarakat lainnya. Mereka tidak punya tempat tinggal yang menentu, bekerja serabutan tanpa penghasilan yang pasti, bahkan dijauhi karena kondisi fisik mereka yang tidak terawat, padahal di sisi lain masyarakat faksi yang berada dibalik rerongsokan dan puing-puing kota tersebut hidup serba berkecukupan. Hal ini juga dapat dilihat melalui stereotype yang dilontarkan Tris kepada factionless, sebelum ia menyadari bahwa kelompok tersebut lebih 'manusiawi' dibandingkan mereka yang terkelompok-kelompokkan oleh sistem faksi.

We are in a factionless storehouse, and the factionless, who are supposed to be scattered, isolated, and without community ... are together inside it. Are together, like a faction. I don't know what I expected of them, but I am surprised by how normal they seem. They don't fight one another or avoid one another. Some of them tell jokes, others speak to each other quietly. Gradually, though, they all seem to realize that we aren't supposed to be there.' (Roth, 2012: 37)

Stereotype yang dibawa oleh Tris ini juga 
Poetika : Jurnal Ilmu Sastra

Vol. V No. 1, Juli 2017
DOI $10.22146 /$ poetika.25810

ISSN 2338-5383 (print) ; 2503-4642 (online) dapat mencerminkan ketakutan-ketakutan masyarakat di dunia nyata. Seperti yang diungkap Tris bahwa 'What if they tell me that I'm not cut out for any faction? I would have to live on the streets, with the factionless. I can't do that. To live factionless is not just to live in poverty and discomfort'. Di dalam dunia nyata kita mengenal pengangguran dan pengemis (bomeless) yang nasibnya mirip dengan factionless dalam cerita. Selain, mereka adalah kelompok yang terasingkan dan terpinggirkan oleh komunitas masyarakat, mereka juga merupakan korban dari kejam dan peliknya sistem kehidupan modern yang segalanya diukur dengan uang. Sehingga yang tidak mampu atau tidak punya kemampuan untuk bekerja akan terlempar dalam jeratan kemiskinan. Tris juga mengatakan 'They are janitors and construction workers and garbage collectors; they make fabric and operate trains and drive buses'. Bahkan menjadi factionless yang bekerja serabutan seperti pemulung dan supir bus masih terlihat hina, seakan-akan pekerjaan seperti itu merupakan sebuah kesalahan.

Situasi serupa pun dapat dilihat dalam Trilogi Hunger Games. Ironi dan kontradiksi juga menjadi bahan narasi utama yang dimanfaatkan oleh Collins. Pembaca dihadapkan oleh narasinarasi yang kontras antara situasi dan kondisi penduduk distrik yang hidup dalam kemiskinan dan keterbatasan dan penduduk Capitol yang rakus dan hidup dalam kemewahan, seperti yang terlihat pada potongan cerita di bawah ini.

The train finally begins to slow and suddenly bright light floods the compartment. We can't belp it. Both Peeta and I run to the window to see what we've only seen on television, the Capi- tol, the ruling city of Panem. The cameras haven't lied about its grandeur. If anything, they have not quite captured the magnificence of the glistening buildings in a rainbow of hues that tower into the air, the shiny cars that roll down the wide paved streets, the oddly dressed people with bizarre hair and painted faces who have never missed a meal. All the colors seem artificial, the pinks too deep, the greens too bright, the yellows painful to the eyes, like the flat round disks of hard candy we can never afford to buy at the tiny sweet shop in District 12.' (Collins, 2008: 31)

'But the money ran out and we were slowly starying to death. There's no other way to put it. I kept telling myself if I could only bold out until May, just May 8th, I would turn twelve and be able to sign up for the tesserae and get that precious grain and oil to feed us. Only there were still several weeks to go. We could well be dead by then. Starvation's not an uncommon fate in District 12. Who hasn't seen the victims? Older people who can't work.' (Collins, 2008: 16)

Pada kutipan pertama di atas dapat dilihat penggambaran kemegahan bangunan-bangunan, jalanan, dan kendaran yang dimiliki oleh penduduk Capitol. Tentunya kemajuan itu sejalan dengan kecanggihan teknologi yang telah menunjang kehidupan masyarakat Capitol. Contohnya, beberapa warna pada bangunan yang megah tersebut bahkan belum pernah dilihat sebelumnya oleh Katniss 'All the colors seem artificial, the pinks too deep, the greens too bright, the yellows painful to the eyes, like the flat round disks of hard candy.' Pembangunan fisik tersebut menjadi sebagian kecil dari simbol kemajuan yang dimiliki Capitol, selain gaya hidup masyarakatnya yang berlebihan sehingga terlihat 'aneh'. Situasi dan kondisi serupa sama sekali tidak terdapat pada distrik-distrik 'jajahan' Capitol. Mereka sangat mengantungkan hidup kepada Capitol. Bahkan banyak diatara mereka yang mati kelaparan, selain karena kehabisan uang, itu juga karena 
ketersediaan bahan pokok dari Capitol sangat terbatas seperti yang terlihat pada kutipan kedua. Sehingga untuk memenuhi itu semua, penduduk distrik harus bertaruh nyawa dalam Hunger Games untuk mendapatkan tesserae (hadiah tahunan atas kemenangan dalam permainan Hunger Games yang berupa kebutuhan pokok).

But here's the catch. Say you are poor and starving as we were. You can opt to add your name more times in exchange for tesserae. Each tessera is worth a meager year's supply of grain and oil for one person. You may do this for each of your family members as well. So, at the age of twelve, I had my name entered four times. Once, because I had to, and three times for tesserae for grain and oil for myself, Prim, and my mother. In fact, every year I have needed to do this. And the entries are cumulative. So now, at the age of sixteen, my name will be in the reaping twenty times. Gale, who is eighteen and has been either belping or single-handedly feeding a family of five for seven years, will have his name in fortytwo times. (Collins, 2008: 9)

Tujuan lain dalam Hunger Games pun sebenarnya untuk mengontrol wilayah distrik agar tetap patuh pada Capitol sebagai pusat kekuasaan, selain juga untuk mengontrol populasi. Melalui Hunger Games, Capitol dapat melakukan kontrol terhadap generasi-generasi muda pada tiap distrik. Dalam hal ini, kekerasan dan eksploitasi anak adalah salah satu representasi dari keterpurukan yang ingin diperlihatkan oleh Collins dalam novelnya.

Selain itu, ada juga James Dashner, melalui trilogi Maze Runnernya, ia menggambarakan distopia dengan menyajikan situasi bumi menjelang kepunahan. Hal tersebut diakibatkan oleh perubahan ekstrim iklim bumi yang hampir memusnahkan seluruh makhluk hidup termasuk melululantahkan seluruh kota-kota di penjuru dunia. Beberapa penduduk yang masih tersisa pun berusaha untuk bertahan hidup dengan bergantung pada lingkungan yang sudah tercemar oleh virus dan bahan-bahan kimiawi yang sewaktuwaktu dapat mengancam hidup mereka.

Not much to tell-bappened a long time ago. The sun flares were completely unexpected and unpredictable, and by the time the scientists tried to warn anyone, it was way too late. They wiped out half the planet, killed everything around the equatorial regions. Changed climates everywhere else. The survivors gathered, some governments combined. Wasn't too long before they discovered that a nasty virus had been unleashed from some disease-control place. Called it the Flare right from the beginning.' (Dashner, 2010: 101)

It was a wasteland. In front of him, a flat pan of $d r y$ and lifeless earth stretched as far as be could see. Not a single tree. Not a bush. No bills or valleys. Just an orange-yellow sea of dust and rocks; wavering currents of heated air boiled on the borizon like steam, floating upward, as if any life out there were melting toward the cloudless and pale blue sky. (Dashner, 2010: 60)

Pada kutipan di atas dapat dilihat bagaimana ekosistem bumi yang hancur, tidak ada lagi tumbuhan hijau, air laut tercemar, gunung-gunung tandus, langit berubah warna dan bahkan sering mengeluarkan cairan beracun yang mematikan. Berbeda dengan Collins, dan Roth, keterpurukan dan kerusakan yang diperlihatkan dalam karya Dahsner ditandai dengan kerusakan iklim bumi. Dalam karya tersebut juga disebutkan bahwa kerusakan bumi itu diawali oleh mewabahnya sebuah virus mematikan yang pada akhirnya membawa bencana 'Wasn't too long before they discovered that a nasty virus had been unleashed from some disease-control place. Called it the Flare right from the beginning'. 
Dengan kata lain, bencana tersebut terjadi juga karena ulah manusia di masa sebelumnya yang telah berlebihan mengekploitasi alam. Korbannya adalah generasi-generasi masa depan yang akan menghuni situasi dan kondisi tersebut.

Dari beberapa penggalan-penggalan teks ini dapat dilihat beberapa kesamaan yang terdapat pada tiga trilogi dystopian sf tersebut yakni kondisi dunia yang dilanda krisis, kehancuran, kesuraman, dan pesimisme. Di kehidupan nyata, isu tentang pencemaran lingkungan dan kerusakan iklim dalam karya-karya Dashner, kemiskinan dan eksploitasi dalam karya Roth dan Collins, tentunya akan sangat akrab bagi pembaca. Masa depan yang ditawarkan dalam karya dystopian sf tersebut mau tidak mau merupakan bagian dari sejarah masa lalu dari cerita yang berusaha dielakkan oleh teks. Dampak dari masa lalu tersebut pun kemudian menjadi masa depan sebagai bentuk peringatan dan kritik yang ditawarkan oleh para penulis dystopian sf di Amerika.

\section{Novel-Novel Satire Dan Sejarah Krisis Amerika}

Jauh sebelum munculnya novel-novel trilogi seperti Hunger Games, Divergent, dan Maze Runner, beberapa novel distopia Amerika awal, dengan satir mengomentari sejarah, khususnya tentang krisis sosial-ekonomi di eranya, salah satunya adalah novel seperti The Republic of the Future: or, Socialism a Reality karya Anna Bowman Dodd. The Republic of the Future: or, Socialism a Reality yang diterbitkan pada tahun 1887 berhasil mengomentari paham sosialis utopia yang merebak di Amerika Serikat (AS) pada waktu itu. Keresahan utama Dodd adalah berbagai inovasi yang dipelopori oleh para penganut utopia di eranya yang mempropagandakan sosialisme, feminism, dan tentunya kemajuan teknologi secara besarbesaran. Ia melihat kemajuan teknologi, yang membawa AS masuk ke dalam era industri, rawan disalahgunakan oleh para "diktator sosialis" yang akan berkuasa dan memonopoli perekonomian. Usaha Dodd tersebut dinilai Pfaelzer, sebagai pembalikan angan-angan yang dijanjikan paham utopis tentang masa depan dengan memproyeksikan pandangan bagaimana mesin di bawah kekuasaan sosialisme hanya bekerja atas hasrat mereka dan mengubah individu menjadi makhluk pasif. Karya Dodd itu, tidak lepas dari dua elemen penting yang melatarbelakangi, yakni novel $A C$ operative Commonwealth karya penulis utopia Lawrence Gronlund dan peristiwa Haymarket pada tahun 1886 yang disebut sebagai puncak propaganda anti-sosialis di AS pada waktu itu. Pfaelzer melanjutkan bahwa Dodd, dalam karyanya, berusaha membangkitkan memori pembaca atas sejarah dan kontradiksinya. Akan tetapi, 'rather than comfort her readers by constructing a fictional antithesis, a utopian resolution, she reminds them of the dangers of contemporary alternatives' (Pfaelzer, 1980: 65). Di saat para penganut utopia menetralkan kekhawatiran masyarakat AS dengan menghadirkan cara yang mudah menuju perubahan, dystopia malah menghadirkan bahaya yang dapat ditimbulkan oleh perubahan tersebut. Menurut Pfaelzer, novel ini sebagai salah satu karya yang satir terhadap sejarah dan sekaligus parodik terhadap novel-novel utopis seperti A Cooperative Commonwealth. 
Respon terhadap sejarah ini juga dapat dilihat pada Looking Further Forward (1890) karya Arthur Vinton. Novel ini menggunakan bingkai narasi Looking Backwards karya Edward Bellamy untuk memperingatkan pembaca bahaya perubahan (recomposition) etnis di kalangan kelas pekerja Amerika. Vinton memperluas karakter, setting, dan desain politis dalam Looking Backward untuk memprediksi konsekuensi dari pola arus imigrasi Cina dan Eropa. Karya Vinton tersebut jelas tertuju pada peristiwa kepanikan ekonomi (economic panic) pada tahun 1873, di mana banyak rakyat AS yang tidak mampu mendapatkan pekerjaan, dikarenakan gelombang besar-besaran imigran Asia, yang dimonopoli oleh etnis Cina, yang masuk ke AS. Peristiwa itupun berujung pada konflik ras, etnis, hingga kelas di AS, karena para imigran dinilai telah merusak tatanan hidup warga asli (angloamerican) AS. Pfaelzer pun menilai novel Looking Further Forward "playing on nativist fears while attacking socialism. Vinton's narrative shows how parody supports the satiric function of dystopia." (Pfaelzer, 1980: 66). Penilaian Pfaelzer ini menunjukkan bahwa dystopia dengan fungsi satir dan parodiknya bekerja dalam rangka memberi peringatan kepada pembaca atas sejarah yang ada.

Pada periode yang berbeda, pasca Perang Dunia II, beberapa novel dystopia muncul merespon dampak yang dihasilkan oleh modernisasi yang menimbulkan krisis. Seperti pada novel yang berjudul Make Room ! Make Room ! (1966) karya Harry Horrison mengangkat isu tentang bahaya yang akan ditimbulkan oleh krisis populasi yang terjadi di New York pada pertengahan abad 20. Ancaman populasi yang merupakah salah satu ketakutan sosial masyarakat AS di tahun 1960an pasca perang dunia II, dimanfaatkan oleh Harrison untuk mempertegas ancaman tersebut bahwa membludaknya populasi hanya akan membawa krisis sosial bagi AS. Di dalam The Encyclopedia of Science Fiction, John Clute pun menilai novel-novel seperti ini mengantisipasi dampak berupa "the exhaustion of resources; the destruction of the environment by pollution; and the social problems of living in crowded conditions" yang menjadi ketakutan masyarakat AS pada waktu itu (Clute, 1995: 685). Di samping itu, Harrison juga berusaha untuk mengangkat isu tentang penggunaan kondom sebagai alternatif untuk menahan tingkat kelahiran dan laju populasi. Kemudian pada tahun 2008, dalam rangka penerbitan kembali novelnya itu oleh penerbit Penguins, Harrison menyisipkan tulisan untuk pembacanya di akhir novel tersebut mengenai prediksi yang ada pada novel yang ditulisnya pada setengah abad lalu itu:

How has this novel stood the test of time? It has been over half a century since I first began working on this book, digging out information on overpopulation, pollution and oil consumption. These were the facts that underlay my story of the future... But how right were my predictions? Pretty bad in most of the general details. I have never believed that science fiction predicts the future. It does not. There are predictions made in the literature; but they are bunches, guess, hopes. Authors shotgun the future with ideas. And, like shotgun pellets bitting a stretch of wall, some will hit the target... Unhappily for mankind the population details, food shortages and oil consumption I wrote about have proven to be too horribly correct... I am not happy about being correct; I wish it had been the other way around. I wish we had controlled population growth and developed green energy sources. 
Perhaps we still can. Dare I be optimistic? I shall try. While you, dear reader, will hopefully read this book and agree with me. (Harrison, 2008: 232-233)

Dalam pernyataannya tersebut, Harrison, mengkonfirmasikan maksud sebenarnya dari novel yang ditulisnya pada tahun 1966. Dapat dilihat bahwa, hal itu dilakukannya untuk mengubah arah pola pikir masyarakat AS dan mendorong pembaca mengenali kebutuhan untuk mengontrol populasi. Singkatnya, bahwa pandangannya tentang dunia yang pada saat itu sedang berada di jalur menuju kegagalan masih sedang berlangsung, sehingga menurutnya novelnya masih sangat relevan untuk dibaca di era sekarang.

\section{Krisis ekonomi amerika serikat tahun 2008} dan trilogi hunger games, maze runner, dan divergent

Jika pola karya-karya dystopia yang satire mengomentari sejarah krisis di masanya, maka dapat ditengarai tiga trilogi Hunger Games, Maze Runner, dan Divergent juga melakukan hal yang serupa. Jika dilihat dari isu-isu yang diangkat, memang jelas bahwa karya-karya tersebut berusaha menyuarakan sebuah peringatan (atau perlawanan) terhadap kondisi krisis yang bisa saja akan dialami oleh pembaca di masa depannya. Apalagi jika melihat awal produksinya, Roth yang mengawali seri pertama dari trilogi Hunger Gamesnya pada tahun 2008 merupakan momen yang bersamaan dengan peristiwa tumbangnya perekonomian Amerika Serikat untuk kesekian kalinya setelah The Great Depression di tahun 1929. Di dalam negeri AS, krisis ini be- rawal dari krisis kredit perumahan yang menyebabkan, banyak warga AS yang terusir dari huniannya. Imbasnya, angka pengangguran meningkat bersama meningkatnya angka pemutusan hubungan kerja (PHK) oleh perusahaan-perusahaan yang terguncang krisis. Maka berbagai lembaga keuangan raksasa seperti perusahaan yang terlibat dalam pemberian kredit, penjaminan kredit, dan asuransi kredit perumahaan (subprime mortgage) pun bangkrut. Hal inipun memaksa pemerintah AS mengucurkan dana talangan kepada perusahaanperusahaan raksasa tersebut untuk menopang perputaran ekonomi AS. Namun, krisis yang sudah akut tidak dapat lagi dihentikan laju rodanya memaksa AS mencapai titik ekonomi terendahnya sepanjang sejarah.

Hal inipun dicurigai sebagai kegagalan sistem kapitalsime liberal yang dijalankan AS. Beberapa ahli sepakat bahwa krisis ini disebabkan oleh tidak adanya regulasi yang mengatur pasar saham Wall Street. Di dalam ideologi kapitalisme liberal, regulasi adalah barang haram. Oleh karena itu mantera yang harus diamalkan adalah deregulasi. Dan itu dilaksanakan di AS sejak pemerintahan Presiden Ronald Reagan, di tahun 1980-an. Reagan menggunakan sistem kapitalisme untuk menghadapi sistem ekonomi terpusat dari komunisme, musuh AS dan Barat dalam Perang Dingin pada waktu itu. Di zaman Presiden Clinton, misalnya, regulasi yang sudah ada sejak Great Depression, yang melarang bank komersial memperluas aktivitasnya dalam berbagai kegiatan financial lain seperti investasi dan asuransi, dideregulasi alias dinyatakan tidak berlaku. Apalagi ketika Alan Greenspan menjadi Pemimpin The Fed, deregulasi 
demi deregulasi dilakukan. Sehingga iklim di sekitar pasar keuangan dan modal AS memang sangat bebas. Alan Greenspan pun dipuji-puji setinggi langit, termasuk oleh koran-koran utama di Indonesia.

Chomsky salah satunya, dalam salah satu tulisannya yang berjudul "Kemorosotan AS: Penyebab dan Konsekuensinya," menilai bahwa transformasi besar-besaran ekonomi politik nasional AS di era Reagan itu sebagai 'zaman keemasan bagi kapitalisme (negara)'. Lebih lanjut Ia mengungkapkan, kemenangan doktrin pasar bebas memberikan pukulan lebih lanjut saat doktrin itu diterjemahkan menjadi deregulasi. Akhirnya, terjadi perubahan kebijakan sistem finansialisasi dan produksi yang menguntungkan korporat dan pemegang modal lainnya dalam melakukan manuver finansial untuk meraup untung sebanyak-banyaknya. Chomsky melanjutkan bahwa "Pemusatan kekayaan yang dihasilkan telah menumbuhkan kekuasaan politik yang lebih besar, mempercepat gerak lingkaran setan yang mengarah pada peningkatan kekayaan secara luar biasa bagi sekelompok orang, sedangkan pendapatan riil mayoritas penduduk sebenarnya mengalami stagnasi" (Chomsky, 2016: 96).

Begitupun dengan The New York Times, dalam editorialnya pada 20 September, dengan sangat keras mengecam sistem kapitalisme liberal yang diterapkan pemerintahan Presiden Bush sebagai sumber malapetaka ini. Menurut editorial itu, rakyat AS harus diberitahu kebenaran yang fundamental bahwa krisis yang sekarang menimpa AS terjadi sebagai hasil sebuah kesen- jangan dan kegagalan sistematik dari pemerintah untuk mengatur dan memonitor aktifitas bangkir, kreditor, pengelola dana (hedge funds), asuransi dan pemain pasar lainnya. Kegagalan pengaturan itu, pada masanya, didasari pada kepercayaan suci dari pemerintahan Bush bahwa pasar dengan tangan silumannya bekerja dengan sangat baik ketika ia dibiarkan sendiri, mengatur dirinya sendiri, mengawasi dirinya sendiri. "Negeri ini sekarang harus membayar mahal harga khayalan itu," tulis editorial tersebut.

Krisis inipun dengan segera bertransformasi menjadi krisis ekonomi dalam negeri jangka panjang. Bagi masyarakat AS, masalah yang utama adalah meningkatnya jumlah pengangguran. Pada level masyarakat dalam negeri, PHK besar-besaran terjadi karena para pemilik perusahan yang memangkas biaya produksi. Otomatis daya beli masyarakat pun ikut turun. Rumah tangga AS yang terkenal dengan tingkat konsumsinya yang sangat tinggi, dipaksa untuk berhemat. Restoranrestoran banyak yang tutup, sementara yang masih buka menerapkan harga krisis. Penduduk miskin yang sebelumnya bisa memperoleh rumah melalui fasilitas kredit murah, kini mendapati kenyataan bahwa rumah mereka disita oleh perusahaan. Organisasi Buruh Internasional (ILO) pun merilis data bahwa, hingga akhir tahun 2009, setidaknya ada sekitar 20 juta masyarakat AS yang kehilangan pekerjaannya selama krisis berlangsung. Hal itu berhasil mencatatkan jumlah pengangguran di atas 200 juta untuk pertama kalinya dalam sejarah AS.

Situasi itu juga dapat dilihat dari data yang dirilis oleh Departemen Ketenagakerjaan AS pada tahun 2008. Data itu menunjukkan tingkat 
pengangguran di AS pada bulan Desember 2007 adalah 4,9\%. Pada bulan Oktober 2009, tingkat pengangguran meningkat menjadi 10,1\%. Jika memperhitungkan para pekerja paruh waktu karena alasan ekonomi, angka tersebut bisa mencapai 16,3\%. Pada bulan Juli 2009, masyarakat yang kehilangan pekerjaan lebih sedikit namun tetap melanjutkan tingkat pengangguran dari 9,5\% menjadi 9,4\%. Hal ini berlanjut pada bulan Agustus, 216.000 orang yang kehilangan pekerjaan tercatat sebagai angka terendah sejak September 2008, namun tingkat pengangguran tetap saja naik menjadi 9,7\%. Pada bulan Oktober 2009, laporan berita mengumumkan bahwa beberapa pengusaha yang memotong pekerjaan karena resesi mulai mempekerjakan mereka kembali. Hingga pada 2013, jumlah pengangguran AS turun diangka 13 juta (Fred DatabasedUnemployed), namun itupun belum dapat menjamin krisis ekonomi di AS membaik.

Semua ini hanyalah salah satu dari sekian banyak krisis yang pernah meluluh-lantahkan perekonomian AS. Tentunya belum menyebutkan krisis-krisis yang terjadi pasca 1975 seperti krisis moneter Asia pada 1998, krisis dot.com pada 2000. Akar krisis ini menghunjam jauh dalam sistem perekonomian dunia dan AS pada umumnya. Jejaknya bisa ditelusuri sejak pasca Perang Dunia II, hingga terjadinya krisis ekonomi pada 1970an dan era presiden Reagan, yang ditandai oleh bangkrutnya sistem Bretton Woods. Intinya, sistem kapitalisme akan selalu berbuah krisis dan pada akhirnya mengorbankan rakyat.

Dapat dilihat di sini bahwa walaupun dalam fiksi dystopia, pembaca dibuat seakan terasingkan jauh dari realitas, namun dalam perkembangannya, kondisi paralel antara narasinarasi distopia dan sejarah terlihat sangat dekat. Hal itu pula yang membuat novel-novel dystopian sf dapat menjadi sangat relevan dengan apa yang terjadi di dunia penulis dan pembaca. Seperti pada pernyatan Harrison yang memperlihatkan bahwa ada korespondensi antara fiksi dan sejarah yang cenderung berulang, seperti sejarah krisis. Korespondensi itu diperlihatkan oleh novel-novel dystopia melalui fungsi satirnya yang membuat pembaca sadar akan kondisinya nyatanya.

Like Suvin, Jameson refers here to the satiric func-
tion of dystopias-the incorporation of historical
reality into the text to make a normative statement
about the world outside the text. Nevertheless we
must consider the fictions which mediate history, as
well as history itself, as necessary structures in a
dystopian text. Dystopias, like utopias and sat-
ires, are historically conditioned genres, and rely on
the readers' recognition of parallels between history
and art: for example, Dodd's revolution is a thin
metaphor for the anarchist riots in Chicago in
1887. Nevertheless, dystopia refers to utopia as
well as to history. (Pfaelzer, 1980: 65)
Kondisi ini pun telah lama menjadi konsentrasi oleh peneliti utopia dan distopia sebelumnya seperti Suvin dan Jameson. Mereka menilai bahwa baik distopia maupun utopia keduanya merupakan sebuah genre yang situasional (conditioned), sehingga dapat dikatakan bahwa fiksi dan sejarah adalah relasional. Kondisi yang relevan antara fiksi dan sejarah terletak pengakuan pembaca itu sendiri para kedekatan narasi-narasi tentang dunia dalam fiksi dengan realitas yang ada.

\section{Kesimpulan}

Berbagai contoh novel-novel dystopia sf 
yang telah dijelaskan, memperlihatkan bahwa keberadaan dystopian sf sangat dipengaruhi oleh kondisi historisnya. Dystopian sf selalu hadir untuk merespon sejarah yang juga secara tidak langsung menunjukkan keterlibatan fiksi popular atas sejarah. Dalam hal ini, dystopian sf mampu memberikan "intervensi" terhadap pengalaman pembaca atas sejarah, baik berupa peringatan ataupun ancaman. Karena itu pula, konten-konten novel dystopian sf yang selalu jauh dari kesan ideal (utopia) dan dekat dari kesan pesimisme justru berhasil menarik empati pembaca.

Meskipun nada peringatan yang digaungkan dystopian sf cenderung terkesan pesimistik, namun di sisi lain novel-novel dystopian sf terbukti dapat menyajikan sisi lain dari kehidupan bagi pembaca yang mungkin selama ini "tabu" atau "terlarang" untuk secara umum diperbincangkan. Terutama yang menyangkut isuisu penindasan dan eksploitasi kelas oleh kelompok penguasa yang dapat dijumpai dalam narasi-narasi dystopian sf. Bukan hanya itu, dystopian sf juga mampu menampilkan isu-isu keterpurukan sosial seperti kemiskinan, kerusakan lingkungan, perang dan pemimpin korup yang realitasnya juga sedang menjadi permasalahan di dunia pembaca. Hal inilah yang menjadi daya tarik dystopian sf di kalangan pembaca fiksi, terutama bagi pembaca-pembaca muda, yang sudah mulai jemu dengan keadaan yang diwariskan kepada mereka saat ini.

Pengakuan seperti ini juga yang tampaknya dapat dijumpai pada novel-novel dystopian sf yang sangat digemari pembaca, khususnya pembaca muda AS, saat ini. Pembaca masih selalu menyimpan kepercayaan bahwa apa yang ada dalam novel-novel dystopian selalu merupakan respon atas kondisi sejarah yang ada. Sehingga tidak heran jika novel-novel dystopian sf seperti Hunger Games kemudian menjadi sangat popular dan banyak menginsiprasi novel-novel setelahnya seperti trilogi Maze Runner dan trilogi Divergent. Dengan hasil penjualan yang tidak biasa, novel-novel tersebut, di masa krisis ekonomi AS, terbukti mampu menarik minat pembaca. Novel tersebut berhasil menjalankan fungsi satirnya dengan mengangkat isu-isu krisis ke permukaan. Hasilnya, pembaca dibuat sadar dengan kompleksitas persoalan dunia yang dihadapinya yang perlahan-lahan membawa situasi dunia semakin memburuk.

\section{Daftar Pustaka}

Adi, Ida Rochani. 2008. Mitos di balik Film Laga AS. Yogyakarta: Gadjah Mada University Press.

Chomsky, 2016. Who Rules The World. Edisi terjemahan bahasa Indonesia oleh Eka Saputra. Yogyakarta: Penerbit Bentang

Collins, Suzanne. 2008. Hunger Games. Pdf version. New York: Scholastic Press

2009. Catching Fire. Pdf version. New York: Scholastic Press 2010. Mockingjay. Pdf version. New York: Scholastic Press

Dahsner, James. 2009. Maze Runner. Pdf version. New York. Delacorte Press 2010. Scorch Trials. Pdf version. New York. Delacorte Press

2011. Death Cure. Pdf version. New York. Delacorte Press

Harrison, Harry. 2008. Make Room! Make Room! London: Penguin Books. Modern Classic Edition 
James, Edward. 1994. Science Fiction in the 20th Century. Oxford: Oxford University Press.

Jenkins, Henry. 2004. Media and Imagination: A Short History of American Science Fiction.

News Release. Bureau of Labour Statistics. US

Department of Labor. https:/ /

www.bls.gov/news.release/pdf/

empsit.pdf. Diakses pada 24 Februari 2017 pukul 23. 58 WIB

Nicholls, Peter \& Clute, John. 1995. The Encyclopedia of Science Fiction. New York: St. Martin's Press

Pfaelzer, Jean. 1980. "Parody and Satire in American Dystopian Fiction of the Nineteenth Century". Science Fiction Studies, Vol. 7, No. 1, Science Fiction on Women, Science Fiction by Women (Mar., 1980), pp. 61-72. SF-TH Inc

Roberts, Adam. 2000. Science Fiction. New York: Routledge

Roth, Veronica. 2011. Divergent. Epub Edition. New York: HarperCollins Publisher 2012. Insurgent. Epub Edition. New York: HarperCollins Publisher 2013. Allegiant. Epub Edition.

New York: HarperCollins Publisher 